\title{
Improving Drinking Water Quality by Remineralisation
}

\author{
Anna Luptáková* and Ján Derco \\ Institute of Chemical and Environmental Engineering, Faculty of Chemical and Food Technology, \\ Slovak University of Technology, Radlinského 9, 81237 Bratislava, SK \\ *Corresponding author: E-mail:anna.luptakova@ stuba.sk \\ $+421908508810$ \\ Received: 07-04-2014
}

\begin{abstract}
The reason of low mineral content in source water is its origin in poorly soluble mineral geological structures. There are many areas with very soft low-mineralised water around the world. All people involved in drinking water treatment as well as some public health experts and producers of chemicals used for water treatment may be interested in the study. Enrichment of drinking water by minerals including calcium and magnesium is very important particularly in regions where drinking water is prepared by desalination. ${ }^{1}$

The aim of this work was to study and intensify the recarbonization process. Half-calcined dolomite in combination with carbon dioxide constitutes the chemistry of the applied method. Advantages of using a fluidised bed reactor contributed also significantly to the process efficiency enhancement. Continuous input of carbon dioxide into the fluidised bed recarbonization reactor resulted in an increase in the recarbonization rate by about one order of magnitude compared with the process in without carbon dioxide addition. Very good fit of experimental data for hydrodynamic characteristics of fluidised bed was obtained using simple model based on the Richardson and Zaki expansion equation. The first order model describes kinetic data from the recarbonization process with a good accuracy. Higher recarbonization rates were observed with smaller particles of half-calcined dolomite.
\end{abstract}

Keywords: Drinking water, fluidised bed reactor, half-calcined dolomite, mineral deficiency, recarbonization, water quality improvement

\section{Introduction}

Drinking water, regardless to its source, is usually subject to one or more of a variety of treatment processes aimed at improving its safety and quality. These processes are selected according to the source water quality and the constituents and contaminants that require removal.

According to the World Health Organization, roles of magnesium and calcium in drinking water and their potential contribution and benefits for health are very relevant. ${ }^{1}$ It is certain that drinking water mineralisation will continue to attract considerable attention and debate because the production of potable water has become a global concern; for many communities, projected population growth and demand exceed conventional available water resources. Water shortages have plagued many communities, and humans have long searched for a solution to Earth's deficient fresh water supplies. ${ }^{2-6}$

Recarbonization is water treatment process to increase its calcium and magnesium content can be applied to enhance the quality of drinking water with very low level of minerals contained. Calcium and magnesium are necessary for human health. In addition to this, serious problems of very soft water are its corrosive and aggressive impacts. Water with very low total hardness is unstable and unbuffered. ${ }^{7-10}$

There are various methods for increasing the mineral content in drinking water, each of them offering advantages and encountering drawbacks. Direct chemical dosage is relative expensive and also results in high concentration of unwanted anions (typically chloride) in water. ${ }^{11}$ Blending of water with more mineralised water may be considered as a low-cost method to increase the concentration of ions in desalinated or very soft water; however, it invariably adds other, undesired, species and unavoidable contamination of the product water with (often) unacceptable amount of unwanted ions occurs. More generally, since the required final water mineral composition usually comprises more than one quality parameter, any mixing approach will invariably fail to meet the required criteria. ${ }^{1-12}$ 
Carbonates and carbon dioxide utilisation is one of the most popular hardening techniques in drinking water technology these days. By penetrating soft water through a limestone bed at a certain flow rate, calcium and bicarbonate ions are gradually introduced to the water through the dissolution process of the calcite grains in the filter bed. With certain benefits in both economic and technical aspects, limestone contactors are gaining more attention in the drinking water industry. ${ }^{13-14}$

However, disadvantage of calcite dissolution processes is that they naturally do not result in the addition of $\mathrm{Mg}^{2+}$ ions to treated water. On the other hand, $\mathrm{Mg}^{2+}$ ions are very much welcome in drinking water for both quality and human health reasons. Recent studies indicate that they may prevent hypertension, atherosclerosis, coronary heart disease, obstetric-gynecologic pathologies: premenstrual syndrome, climacterium, post-menopausal osteoporosis. ${ }^{15-18}$

Practical alternative processes that have been proposed for the addition of $\mathrm{Mg}^{2+}$ ions to water include direct chemical dosage and dissolution of dolomite minerals. The main advantage of this process is the enrichment water with both elements. ${ }^{7}$

The main aim of the work was to study the enrichment of treated water with calcium and magnesium. Halfcalcinated dolomite in combination with carbon dioxide was used as the donor of deficient micronutrients. A fluidised bed reactor was used with the aim to maintain homogeneous conditions, and increase the interface surface area as well as the recarbonization process rate and performance. Hydraulic characteristics of fluidised bed and the influence of water and carbon dioxide flows and reaction time on the recarbonization processes were studied.

\section{Theoretical}

\section{1. Chemistry of Investigated Process}

Experiments aimed at increasing $\mathrm{Ca}^{2+}$ and $\mathrm{Mg}^{2+}$ content in water were carried out in a lab-scale fluidisedbed reactor. This technique offers potential for high reaction surface area and reaction rate. Despite these advantages, fluidised bed is relatively rarely used in drinking water treatment, and thus it represents a new approach in drinking water industry.

Half-calcined dolomite, also called half-burnt dolomite $\left(\mathrm{MgO} \cdot \mathrm{CaCO}_{3}\right)$, was used as the recarbonization agent in this study. The advantage of this material is that it supplies both minerals, i.e. magnesium and calcium ions, in comparison to other materials, e.g. limestone or lime. This feature of the process is important for human health as well as for water stability. follows:

Half-calcined dolomite and $\mathrm{CO}_{2}$ react with water as

$$
\mathrm{MgO}+2 \mathrm{CO}_{2}+\mathrm{H}_{2} \mathrm{O}>\mathrm{Mg}\left(\mathrm{HCO}_{3}\right)_{2}
$$

$$
\mathrm{CaCO}_{3}+\mathrm{CO}_{2}+\mathrm{H}_{2} \mathrm{O}>\mathrm{Ca}\left(\mathrm{HCO}_{3}\right)_{2}
$$

Half-calcined dolomite is usually used for deacidification of water with a high content of natural carbon dioxide. It is a special alkaline mass consisted of dolomite, which is a mixture of about $50 \%$ of $\mathrm{CaCO}_{3}$ and $50 \%$ of $\mathrm{MgCO}_{3}$. When calcined at $650-800{ }^{\circ} \mathrm{C}$, magnesium carbonate is decomposed to $\mathrm{MgO}$ and $\mathrm{CaCO}_{3}$ remains intact during the calcination. The result is a porous $\mathrm{MgO} \cdot \mathrm{CaCO}_{3}$ mixture which reacts with carbon dioxide approximately three times faster than marble. ${ }^{7}$

\section{2. Hydraulics of Fluidised Bed Reactor}

The threshold velocity of fluidised bed can be determined based on experimental dependence of the pressure loss on the superficial velocity flow. The pressure loss drops when the threshold velocity is stabilised at a constant value. ${ }^{19}$

A partial goal of this work was to verify a simple model for the description of hydrodynamics of the recarbonization fluidised bed reactor. The overall bed voidage is given by:

$$
\varepsilon=\frac{\mathrm{V}_{\mathrm{p}}}{\mathrm{Ah}}
$$

where $\varepsilon$ is fluidised bed porosity, dimensionless

$\mathrm{V}_{\mathrm{p}}$ - total volume of particles of fluidised bed, $\mathrm{m}^{3}$

$\mathrm{A}$ - bed cross-sectional area, $\mathrm{m}^{2}$

$\mathrm{h}$ - overall fluidised bed height, $\mathrm{m}$.

The Richardson and Zaki correlation ${ }^{20}$ is widely used to describe the expansion of the fluidised bed:

$$
\varepsilon=\sqrt{\frac{\mathrm{W}}{\mathrm{u}_{\mathrm{t}}}}
$$

where $\mathrm{w}$ is superficial velocity, $\mathrm{m} \cdot \mathrm{s}^{-1}$

$\mathrm{u}_{\mathrm{t}}-$ particle terminal velocity, $\mathrm{m} \cdot \mathrm{s}^{-1}$

$\mathrm{n}-$ bed expansion index, dimensionless

After a rearrangement of Eqs. (1) and (2), the following relation can be derived:

$$
\mathrm{h}=\frac{\mathrm{V}_{\mathrm{p}}}{\mathrm{A}(1-\varepsilon)}
$$

\section{3. Water Saturation With Calcium and Magnesium}

The first order equation was used to describe the kinetics of the recarbonization process:

$$
\frac{d C}{d t}=d_{c}\left(C_{e k v}-C\right)
$$


where $\mathrm{C}_{\mathrm{t}}$ is $\mathrm{Ca}^{2+}+\mathrm{Mg}^{2+}$ concentration $\left[\mathrm{mmol} . \mathrm{L}^{-1}\right.$ ] in reaction time $\mathrm{t}$,

$$
\begin{aligned}
\mathrm{C}_{\mathrm{ekv}}- & \text { equilibrium concentration value/s for } \mathrm{Ca}^{2+} \\
& \text { and/or } \mathrm{Mg}^{2+} \text { content }\left[\mathrm{mmol} \cdot \mathrm{L}^{-1}\right], \\
\mathrm{d}_{\mathrm{c}}- & \text { dissolution coefficient for } \mathrm{Ca}^{2+} \text { and/or } \mathrm{Mg}^{2+} \\
& \text { ions }\left[\mathrm{min}^{-1}\right], \\
\mathrm{t}- & \text { reaction time of the recarbonization process } \\
& {[\text { min]. }}
\end{aligned}
$$

Integration of Eq. (6) between the boundary values of $\mathrm{C}=\mathrm{C}_{0}$ and $\mathrm{t}=0$ and $\mathrm{t}=\mathrm{t}$ and for the case that $\mathrm{C}_{0}=0$ yields:

$$
\mathrm{C}_{\mathrm{t}}=\mathrm{C}_{\mathrm{ekv}}\left(1-\mathrm{e}^{(-\mathrm{dc}) \mathrm{t}}\right)
$$

\section{Materials and Methods}

\section{1. Samples of Treated Water}

Recarbonization experiments were carried out with demineralised water which was used as model drinking/treated water. The aim was to investigate recarbonization of water with very low mineralisation. Preliminary experiments with different hardening agents were carried out also with real drinking water. Performing of experimental measurements with real drinking water with low calcium and magnesium contend are planned in near future.

\section{2 Half-calcined Dolomite}

Experimental measurements were performed with two fractions of half-calcined dolomite particles, i.e. sieve fractions in the ranges $0.70-1.00 \mathrm{~mm}$ and $1.00-1.25 \mathrm{~mm}$. Half-calcined dolomite provided by the company KAS Malé Kršten̆any (Slovak Republic) was used in our study.

The density of $2440.7 \mathrm{~kg} \cdot \mathrm{m}^{-3}$ of the half-calcinated particles was determined by the pycnometric method. ${ }^{21}$ The metal content in an aqueous extract of half-calcined dolomite was determined by an accredited laboratory,

Table 1. Metal content (mg. $\mathrm{L}^{-1}$ ) in an aqueous extract of half-calcined dolomite.

\begin{tabular}{ll}
\hline Metal elements & Concentrations $\left(\mathbf{m g} \cdot \mathbf{L}^{\mathbf{1}}\right)$ \\
\hline Arsenic (As) & $<0.02$ \\
Cadmium (Cd) & $<0.003$ \\
Argentum (Ag) & $<0.01$ \\
Copper $(\mathbf{C u})$ & $<0.01$ \\
Lead $(\mathbf{P b})$ & $0.011 \pm 0.003$ \\
Barium $(\mathbf{B a})$ & $<0.01$ \\
Chrome (Cr) & $<0.01$ \\
Nickel (Ni) & $<0.01$ \\
Iron (Fe) & $<0.05$ \\
Manganese (Mn) & $<0.01$ \\
Magnesium (Mg) & $10.7 \pm 1.6$ \\
Calcium $(\mathbf{C a})$ & $1.62 \pm 0.35$ \\
\hline
\end{tabular}

VÚSAPL Nitra, Slovakia, and the values are summarised in Table 1.

Due to the low content of heavy metals it can be assumed that when releasing the target elements from halfcalcined dolomite, no significant release of other heavy metals, which would cause impairment of the quality of the treated water, occurs.

The use of such materials is governed by STN EN 1017/AC (2008). ${ }^{22}$ This European Standard is applicable to half calcined-dolomite which is used in water treatment for drinking water, STN EN 1017/AC (2008)-Chemicals Used for Treatment of Water Intended for Human Con-

\begin{tabular}{|c|c|c|}
\hline Fraction & 0.70-1.00 mm & $1.00-1.25 \mathrm{~mm}$ \\
\hline Sample mass & $0.6552 \mathrm{~g}$ & $0.5000 \mathrm{~g}$ \\
\hline Specific surface area & $13.3937 \mathrm{~m}^{2} \mathrm{~g}^{-1}$ & $9.8996 \mathrm{~m}^{2} \mathrm{~g}^{-1}$ \\
\hline Pore specific volume & $0.0588 \mathrm{~cm}^{3} \mathrm{~g}^{-1}$ & $0.0113 \mathrm{~cm}^{3} \mathrm{~g}^{-1}$ \\
\hline
\end{tabular}
sumption-Half-Calcined Dolomite. ${ }^{22}$

Specific surface area and specific pore volume of half-calcined dolomite were measured on a Sorptomatic 1900 (Thermo Fisher Scientific Inc, USA). The results are summarised in Table 2.

Table 2. Results of Sorptomatic measurements.

\section{3. Experimental Equipment}

Experimental measurements aimed at increasing the $\mathrm{Ca}^{2+}$ and $\mathrm{Mg}^{2+}$ content in treated water were carried out in a lab-scale fluidised-bed recarbonization reactor (FBRR). A scheme as well as a picture of the designed, constructed and tested FBRR are shown in Fig. 1. Fluidised bed technique shows potential for reaction surface area and volumetric reaction rate enhancement and represents a novel approach in drinking water industry.

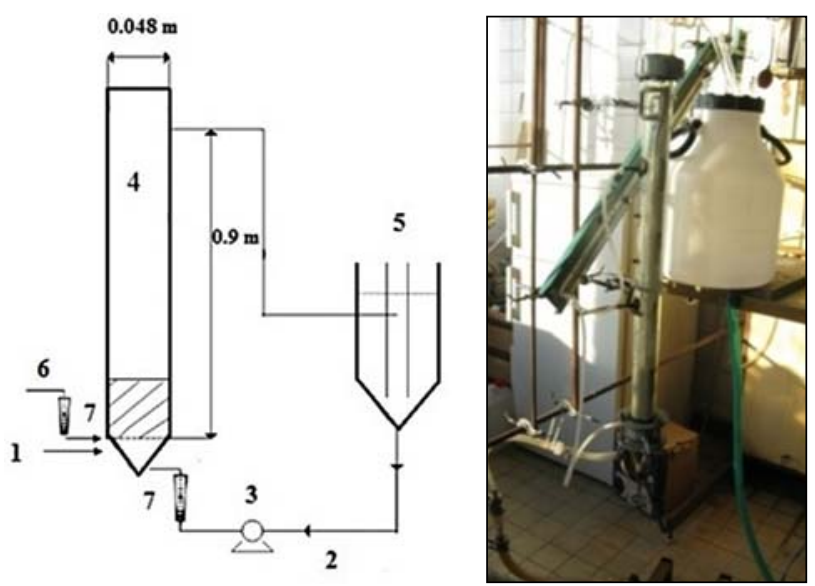

Figure 1. Scheme of lab-scale equipment of FBRR.

(1- treated water inlet, 2 - external recirculation, 3 - pump, 4 reactor with fluidised bed, 5 - settling and storage tank, 6 - inlet of $\mathrm{CO}_{2}, 7$ - flow meter) 
A glass reactor with the cross-sectional area of $19.6 \mathrm{~cm}^{2}$ and the height of $90 \mathrm{~cm}$ was used for experimental measurements. The reactor was fed with the fraction of half-calcined dolomite at the beginning of the experiment and it was operated in the batch mode with regard to the solid phase and in the continuous flow mode with regard to the treated water and carbon dioxide. Treated water was accumulated in a storage vessel and recirculated into FBRR. Such operational mode was selected with the aim to prepare a certain volume of treated water enhanced with calcium and magnesium and potentially use such enriched water for the enrichment of untreated soft water with the target micronutrients by mixing of relevant amounts of treated and untreated water.

\section{4. Analytical Methods and Procedures}

The recarbonization process was investigated by performing chemical analysis focussing mainly on monitoring of conductivity, $\mathrm{ANC}_{4.5}$ (acid neutralizing capacity), $\mathrm{BNC}_{8,3}$ (base neutralizing capacity), $\mathrm{Ca}^{2+}+\mathrm{Mg}^{2+}$, $\mathrm{Ca}^{2+}, \mathrm{Mg}^{2+}, \mathrm{pH}$. Conductivity was measured by a conductometer WTW Multi 3420. Concentrations of calcium and magnesium ions were determined by the complexometric method using an indicator Eriochrome Black T. Chelatometric determination of calcium was carried out with EDTA using murexid as the indicator (from pink to violet). The content of magnesium was calculated from the results of the total content of $\mathrm{Ca}^{2+}+\mathrm{Mg}^{2+}$ and the chelatometric determination of calcium. The $\mathrm{ANC}_{4.5}$ value was determined by titration of water samples against $\mathrm{HCl}$ with the concentration of $0.1 \mathrm{~mol} \cdot \mathrm{L}^{-1}$ in the presence of Methyl Orange as the indicator. The $\mathrm{BNC}_{8.3}$ value was determined by titration of water samples using $\mathrm{NaOH}$ as the titrant in the concentration of $0.1 \mathrm{~mol} \cdot \mathrm{L}^{-1}$ applying phenoftalein as the indicator. ${ }^{23} \mathrm{pH}$ was measured by a $\mathrm{pH}$-meter JENWAY 3510.

\section{5. Design of Experiments}

The first set of experiments focussing on the selection of the recarbonization material with particles fraction of 2.0-4.0 mm for each tested material (half-calcined dolomite, dolomite, calcite), demineralised water and real untreated water sample with very low total hardness $(0.3$ $\mathrm{mmol} \cdot \mathrm{L}^{-1}$ ) were realised. Homogenisation of the suspensions was maintained by shaking in jars. The duration of each experiment was 60 min.

Recarbonization experiments were carried out with two different fractions of half-calcinated dolomite, i.e. $0.70-1.00$ and $1.00-1.25$, at two different water flow velocities (threshold velocity and about three times of the threshold value), and with and without carbon dioxide addition $\left(\mathrm{Q}_{\mathrm{CO} 2}=0\right.$ or $\left.0.9 \mathrm{~L} \cdot \mathrm{min}^{-1}\right)$.

The first set of measurements was performed with the particles fraction of half-calcined dolomite from 0.70 to $1.00 \mathrm{~mm}$. The experiments were carried out in FBRR at the threshold velocity $\left(\mathrm{w}_{\mathrm{p}}=0.011 \mathrm{~m} \cdot \mathrm{s}^{-1}\right)$ and at the velocity of $0.039 \mathrm{~m} \cdot \mathrm{s}^{-1}$. These measurements were carried out without an addition of $\mathrm{CO}_{2}$. The dose of the material was $360 \mathrm{~g} . \mathrm{CO}_{2}$ was injected into fluidised bed reactor through trough a fine-bubble porous distribution element. Samples for parameters assessment were taken from storage tank.

\section{6 Processing of Experimental Data}

Parameter values of applied models (Eqs. (1) to (3), (5)) were calculated by the grid search optimisation procedure. ${ }^{24}$ The residual sum of squares $\left(S_{\mathrm{r}}^{2}\right)$ between the observed and the calculated values of fluidised bed expansion given by the model, divided by its number of degrees of freedom, $v$ (the number of observations less the number of parameters estimated), was used as the objective function.

\section{Results and Discussion}

\section{1. Hydraulics of Fluidised Bed Reactor}

Values of treshold fluidisation velocity for both fractions of half-calcined dolomite were determined experimentally. The value $\mathrm{w}_{\mathrm{p}}=0.011 \mathrm{~m} \cdot \mathrm{s}^{-1}$ was obtained for the particles fraction from 0.70 to $1.00 \mathrm{~mm}$ based on the evaluation of experimental pressure drop dependencies on the superficial velocity. ${ }^{25}$ Likewise, the value $\mathrm{w}_{\mathrm{p}}=0.0147 \mathrm{~m} . \mathrm{s}^{-1}$ was evaluated for particles fraction from 1.00 to $1.25 \mathrm{~mm}$. Measurements of threshold fluidisation velocity in the laboratory FBRR were performed and the values were applied as reference values for kinetic measurements.

The value of the expansion index, ' $n$ ', was obtained by fitting experimental data of bed voidage calculated from fluidised bed height measured at various superficial velocity values. Parameters of Eq. (4) were obtained by nonlinear optimisation of the grid search method. ${ }^{24}$ The value of bed expansion index, ' $n$ ', of 2.96 was found by the evaluation of experimental data.

\section{2. Selection of Recarbonization Material}

Before the recarbonization experiments, the selection of the most convenient recarbonization material, i.e. donor/source of calcium and magnesium, was done. Dolomite, half-calcined dolomite, and calcite were tested as potential materials. The results of the enrichment of water samples with calcium and magnesium $\left(\mathrm{C}_{\mathrm{ekv}}\right)$ for individual materials and water samples during 60 minutes of the contact time are summarised in Table 3. Parameters of Eq. (5) were obtained by nonlinear optimisation of the grid search method. ${ }^{24}$ In the case of real raw water samples, the objective function was modified by adding an initial content of $\left(\mathrm{Ca}^{2+}+\mathrm{Mg}^{2+}\right)$. Time dependencies of experimental and 
calculated (Eq. 7) $\mathrm{C}_{\mathrm{ekv}}$, values, i.e. $\left(\mathrm{Ca}^{2+}+\mathrm{Mg}^{2+}\right)$ contents, for the performed experiments are illustrated in Figure 3.

From Table 3 and Figure 2 it is obvious that the best results were obtained with half-calcined dolomite. The $\left(\mathrm{Ca}^{2+}+\mathrm{Mg}^{2+}\right)$ enrichment rate of raw water was higher by $33 \%$ in comparison with the recarbonization of demineralised water.

On the other hand, magnezium content $(84.9 \%)$ in treated water was significantly higher in comparison to the calcium content $(15.1 \%)$. The reason is the higher magnesium content in half-calcined dolomite (Tab. 1).

Table 3. Kinetic parameters and correlation coefficients. (D-dolomite; HFCD-half-calcined dolomite; C-calcite).

\begin{tabular}{lccc}
\hline Exp. & $\mathbf{C}_{\text {ekv }}\left[\mathbf{m m o l} \cdot \mathbf{L}^{-\mathbf{1}}\right]$ & $\mathbf{d}_{\mathbf{c}}\left[\mathbf{m i n}^{\mathbf{- 1}}\right]$ & $\boldsymbol{r}_{X Y}\left[\mathbf{m i n}^{\mathbf{- 1}}\right]$ \\
\hline HFCD + untreat.w. & 1.2 & 0.009 & 0.9575 \\
HFCD + demi.w. & 0.7 & 0.014 & 0.9904 \\
D + untreat.w. & 0.7 & 0.003 & 0.9003 \\
D + demi.w. & 0.3 & 0.006 & 0.9047 \\
C + demi.w. & 0.1 & 0.040 & 0.9692 \\
\hline
\end{tabular}

Notes: $\mathrm{C}_{\text {ekv }}$-equilibrium concentration values for $\mathrm{Ca}^{2+}$ and $\mathrm{Mg}^{2+}$ content $\mathrm{d}_{\mathrm{c}}$-dissolution coefficient for $\mathrm{Ca}^{2+}$ and $\mathrm{Mg}^{2+}$ ions

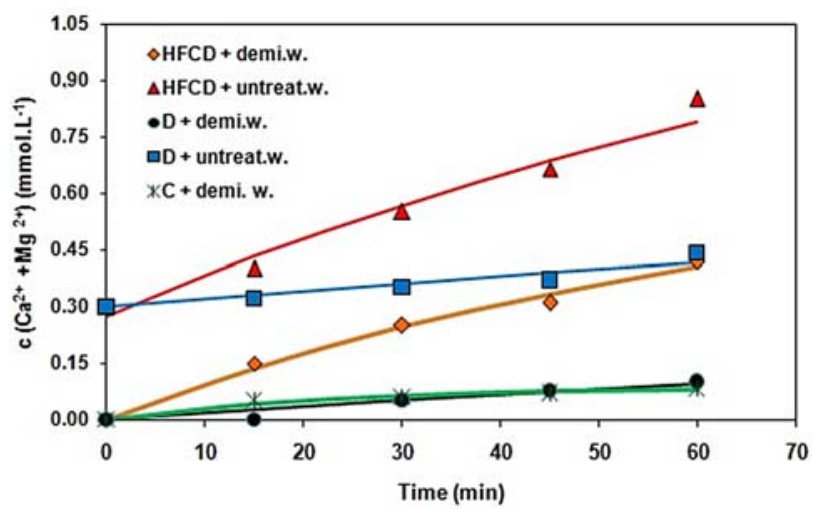

Figure 2. Time dependencies of $\left(\mathrm{Ca}^{2+}+\mathrm{Mg}^{2+}\right)$ content using different recarbonization agents-experimental values (points) and calculated values (lines).

The results from experiments using dolomite show that the magnesium content $(45.5 \%)$ in treated water was quite similar to the calcium content $(54.5 \%)$. Magnesium content was quite low (18.4\%) compared to the calcium content $(81.6 \%)$ obtained in experiments with calcite.

Decision to continue to use half-calcined dolomite in experiments was based on higher rate of the recarbonization (Fig. 2.) (Table 3.).

\section{3. Recarbonization Process in Fixed Bed and Fluidised Bed Reactors}

The following experiments of increasing $\left(\mathrm{Ca}^{2+}+\right.$ $\mathrm{Mg}^{2+}$ ) levels in water were performed in fixed bed and fluidised bed reactors. The particles of half-calcined dolomite (fraction from 0.70 to $1.00 \mathrm{~mm}$ ) were used to increase the $\mathrm{Ca}^{2+}$ and $\mathrm{Mg}^{2+}$ content in demineralised water.

The highest enrichment with the target elements was observed within 30 minutes of the processes in both reactors. The velocity of $\left(\mathrm{Ca}^{2+}+\mathrm{Mg}^{2+}\right)$ concentration increase in an FBRR was twice that in the fixed bed reactor (Table 4).

Observed maximum concentration of $\left(\mathrm{Ca}^{2+}+\mathrm{Mg}^{2+}\right)$ in the fluidised bed reactor was twofold higher than that achieved in the fixed bed reactor (Fig. 4). It is obvious that the fluidised bed reactor offers higher potential for the intensification of the recarbonization process.

Table 4. Kinetic parameters and correlation coefficients.

\begin{tabular}{lccc}
\hline Exp. & $\mathbf{C}_{\mathrm{ekv}}\left[\mathbf{m m o l} \cdot \mathbf{L}^{-\mathbf{1}}\right]$ & $\mathbf{d}_{\mathbf{c}}\left[\mathbf{m i n}^{\mathbf{- 1}}\right]$ & $\boldsymbol{r}_{X Y}\left[\mathbf{m i n}^{-\mathbf{1}}\right]$ \\
\hline fixed bed & 0.4 & 0.032 & 0.9768 \\
fluidised bed & 0.7 & 0.060 & 0.9999 \\
\hline
\end{tabular}

Notes: $\mathrm{C}_{\text {ekv }}$-equilibrium concentration values for $\mathrm{Ca}^{2+}$ and $\mathrm{Mg}^{2+}$ content $\mathrm{d}_{c}$-dissolution coefficient for $\mathrm{Ca}^{2+}$ and $\mathrm{Mg}^{2+}$ ions

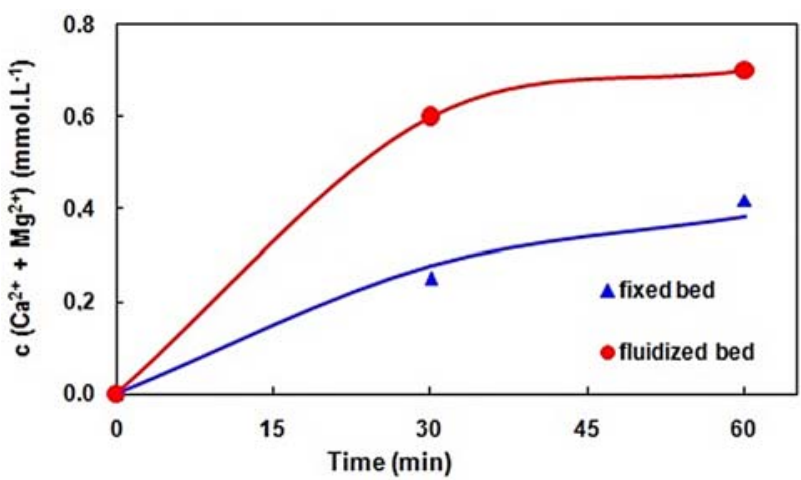

Figure 3. Time dependencies of total hardness increase using halfcalcined dolomite in a fix bed reactor and in a fluidised bed reactor-experimental values (points) and calculated values (lines).

Magnezium content $(86.4 \%)$ in treated water was significantly higher in comparison to the calcium content $(13.6 \%)$ in the fixed bed. Similar results were obtained also in the fluidised bed (magnesium $-85.7 \%$, calcium $-14.3 \%)$.

\section{4. Recarbonization Experiments in Fluidised Bed Reactor}

Experimental and calculated time dependencies of $\left(\mathrm{Ca}^{2+}+\mathrm{Mg}^{2+}\right)$ ions in treated water are ploted in Fig. 4 . Eq. (7) was used to fit the experimental data. The values of parameters $\left(\mathrm{C}_{\mathrm{ekv}}, \mathrm{d}_{\mathrm{c}}\right)$ and correlation coefficients $\left(\mathrm{r}_{\mathrm{XY}}\right)$ are given in Table 5 .

Magnezium content $(85.7 \%)$ in treated water was significantly higher than the calcium content $(14.3 \%)$ at 


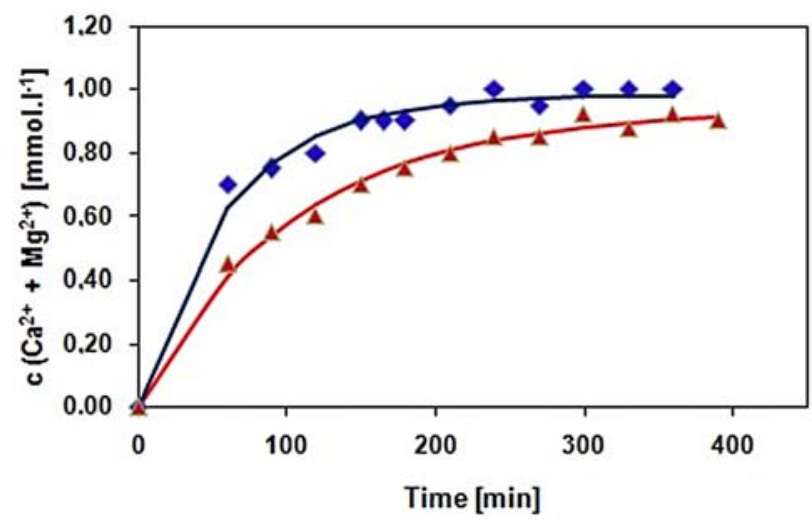

Figure 4. Time dependencies of $\left(\mathrm{Ca}^{2+}+\mathrm{Mg}^{2+}\right)$ content during recarbonization experiments in FBRR $\left(\mathrm{Q}_{\mathrm{CO} 2}=0 \mathrm{~L} \cdot \mathrm{min}^{-1}\right):(\diamond) \mathrm{w}_{1}=$ $0.011 \mathrm{~m} \cdot \mathrm{s}^{-1},(\boldsymbol{\Lambda}) \mathrm{w}_{2}=0.039 \mathrm{~m} \cdot \mathrm{s}^{-1}$-experimental values (points) and calculated values (lines).

lower superficial velocity. Similar results were obtained at higher superficial velocity (magnesium- $79.9 \%$, calcium $-20.1 \%)$.

Table 5. Kinetic parameters and correlation coefficients; $\left(\mathrm{w}_{\mathrm{CO} 2}=0\right.$ L. $\mathrm{min}^{-1}$ and $\mathrm{w}_{\mathrm{CO} 2}=0.09$ L. $\mathrm{min}^{-1}$ )

\begin{tabular}{|c|c|c|c|}
\hline \multirow[b]{2}{*}{$\mathrm{w}\left[\mathrm{ms}^{-1}\right]$} & \multicolumn{2}{|c|}{$\mathbf{Q}_{\mathrm{CO} 2}=0$ L.min - $^{-1}$} & \multirow[b]{2}{*}{$r_{X Y}\left[\min ^{-1}\right]$} \\
\hline & $\mathrm{C}_{\mathrm{ekv}}\left[\mathrm{mmol} \cdot \mathrm{L}^{-1}\right]$ & $d_{c}\left[\min ^{-1}\right]$ & \\
\hline$\overline{0.011}$ & 1.0 & 0.0168 & 0.9845 \\
\hline 0.039 & 0.9 & 0.0095 & 0.9915 \\
\hline$w\left[\mathrm{~ms}^{-1}\right]$ & $\begin{array}{c}\mathbf{Q}_{\mathrm{CO} 2}=0,09 \mathrm{l} . \mathrm{m} \\
\mathrm{C}_{\mathrm{ekv}}\left[\mathrm{mmol} \cdot \mathrm{L}^{-1}\right]\end{array}$ & $\mathrm{d}_{\mathrm{c}}^{-1}\left[\min ^{-1}\right]$ & $r_{X Y}\left[\mathrm{~min}^{-1}\right]$ \\
\hline$\overline{0.011}$ & 87.1 & 0.0007 & 0.9959 \\
\hline 0.039 & 88.1 & 0.0010 & 0.9870 \\
\hline
\end{tabular}

Notes: $\mathrm{C}_{\text {ekv }}$-equilibrium concentration values for $\mathrm{Ca}^{2+}$ and $\mathrm{Mg}^{2+}$ content $\mathrm{d}_{c}$-dissolution coefficient for $\mathrm{Ca}^{2+}$ and $\mathrm{Mg}^{2+}$ ions

Very close concentration values are obvious from Fig. 4 and Table 5, slightly higher values of the dissolution rate and higher dynamics of the process can be concluded for lower superficial velocity (longer retention time). However, differences between the results of both measurements are relatively low. Relatively low calculated concentration values obtained in both experiments can be attributed to the limitation of the process without $\mathrm{CO}_{2}$ addition.

The second set of measurements was performed under similar conditions as the previous experimental set. The main difference was that the supply of $\mathrm{CO}_{2}(0.09$ $\mathrm{L} \cdot \mathrm{min}^{-1}$ ) was maintained during these measurements.

Experimental and calculated time dependencies of $\left(\mathrm{Ca}^{2+}+\mathrm{Mg}^{2+}\right)$ ions in treated water are presented in Fig. 5 . Similarly to the previous experimental set, Eq. (7) was used to fit experimental data. The values of parameters $\left(\mathrm{C}_{\text {ekv }}, \mathrm{d}_{\mathrm{c}}\right)$ and correlation coefficients $\left(\mathrm{r}_{\mathrm{XY}}\right)$ are given in Table 4 .

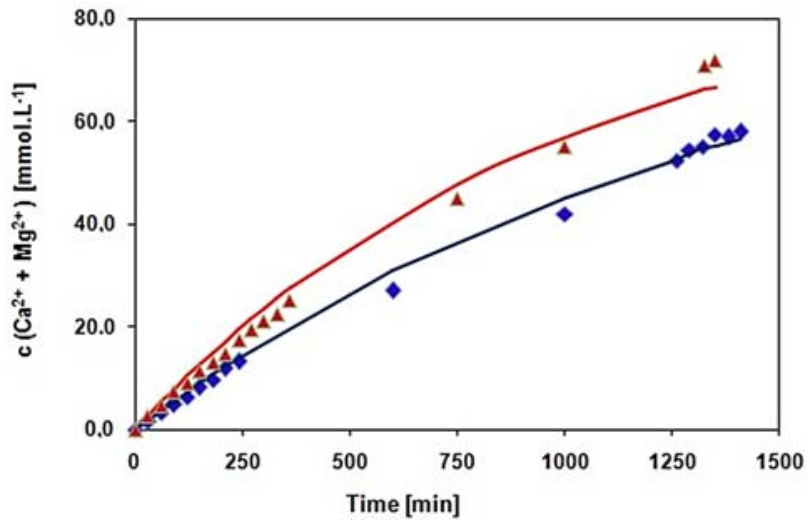

Figure 5. Time dependencies of $\left(\mathrm{Ca}^{2+}+\mathrm{Mg}^{2+}\right)$ content during recarbonization experiments in FBRR $\left(\mathrm{Q}_{\mathrm{CO} 2}=0.09 \mathrm{~L} \cdot \mathrm{min}^{-1}\right)$ : $(\bullet)$ $\mathrm{w}_{1}=0.011 \mathrm{~m} \cdot \mathrm{s}^{-1},(\boldsymbol{\Delta}) \mathrm{w}_{2}=0.039 \mathrm{~m} \cdot \mathrm{s}^{-1}$-experimental values (points) and calculated values (lines).

Significantly higher values of experimental values were obtained from these experiments in equal reaction times compared to the first experimental set (Fig. 4).

Magnezium content (82.2\%-92.6\%) in treated water was significantly higher in than the calcium content $(17.8 \%-7.4 \%)$.

The following set of measurements was performed with the particles fraction from 1.00 to $1.25 \mathrm{~mm}$ at the threshold fluidised velocity while maintaining the $\mathrm{CO}_{2}$ supply of $0.09 \mathrm{~L} \cdot \mathrm{min}^{-1}$.

Experimental and calculated time dependencies of $\left(\mathrm{Ca}^{2+}+\mathrm{Mg}^{2+}\right)$ ions for both fractions are ploted in Fig. 6 . Similarly to previous experimental sets, Eq. (7) was used to describe the experimental data. The values of parameters $\left(\mathrm{C}_{\text {ekv }}, \mathrm{d}_{\mathrm{c}}\right)$ and correlation coefficients $\left(\mathrm{r}_{\mathrm{XY}}\right)$ are given in Table 6.

When comparing the results measured in the presence of carbon dioxide (Figs. 5-6) with the preliminary results carried out in its absence (Figs. 2-3), significantly higher calcium and magnesium content was measured in

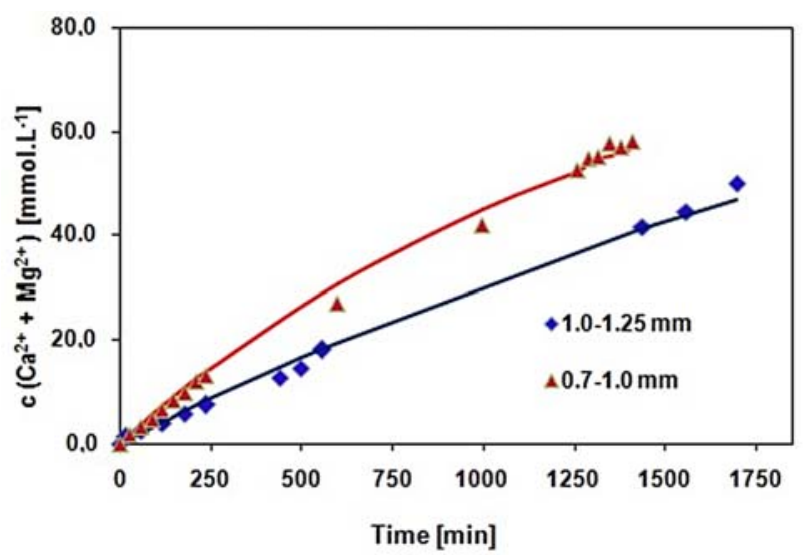

Figure 6. Time dependencies of $\left(\mathrm{Ca}^{2+}+\mathrm{Mg}^{2+}\right)$ content during recarbonization experiments in $\mathrm{FBRR}\left(\mathrm{Q}_{\mathrm{CO} 2}=0.09 \mathrm{~L} \cdot \mathrm{min}^{-1}\right)$-experimental values (points) and calculated values (lines). 
Table 6. Kinetic parameters and correlation coefficients.

\begin{tabular}{lccc}
\hline Fraction $[\mathbf{m m}]$ & $\mathbf{C}_{\mathbf{e k v}}\left[\mathbf{m m o l} \cdot \mathbf{L}^{-\mathbf{1}}\right]$ & $\mathbf{d}_{\mathbf{c}}\left[\mathbf{m i n}^{\mathbf{- 1}}\right]$ & $\boldsymbol{r}_{X Y}\left[\mathbf{m i n}^{\mathbf{- 1}}\right]$ \\
\hline $\mathbf{0 . 7 0 - 1 . 0 0}$ & 87.1 & 0.0007 & 0.9959 \\
$\mathbf{1 . 0 0 - 1 . 2 5}$ & 108.5 & 0.0003 & 0.9974 \\
\hline
\end{tabular}

Notes: $\mathrm{C}_{\text {ekv }}$-equilibrium concentration values for $\mathrm{Ca}^{2+}$ and $\mathrm{Mg}^{2+}$ content $d_{c}$-dissolution coefficient for $\mathrm{Ca}^{2+}$ and $\mathrm{Mg}^{2+}$ ions

treated water, i.e. values by about 55 times higher than those recommended by the Slovak legislation. These results also suggest that this process is an available strategy for the preparation of recarbonization concentrate as a base for raw drinking water enrichment with calcium and magnesium.

However, magnezium content $(85.9 \%-92.6 \%)$ in treated water was significantly higher than the calcium content $(14.1 \%-7.4 \%)$.

Higher dynamics of enrichment was observed when using smaller particles (higher specific surface), as expected. On the other hand, higher value of equilibrium concentration were calculated (Eq. 7) for higher fraction.

Based on the results presented, and taking into account the experience with the recarbonization fluidised bed reactor with two different fractions, we have decided to pursue further research using the larger particles.

\section{Conclusion}

Preliminary results of treated water recarbonization in a fluidised bed reactor are presented. Basic physical and chemical characteristics of half-calcined dolomite were measured. Before the recarbonization experiments, the selection of the most convenient recarbonization material, i.e. donor/source of calcium and magnesium, was done. Dolomite, half-calcined dolomite, and calcite were tested as potential source materials. It is obvious that the best results were obtained using half-calcined dolomite. The $\left(\mathrm{Ca}^{2+}+\mathrm{Mg}^{2+}\right)$ enrichment rate of raw water was higher by $33 \%$ in comparison to the recarbonization of demineralised reference water.

Recarbonization experiments were carried out with two half-burned particle fractions, at two different velocity flows and both in the presence and absence of carbon dioxide.

Utilisation of half-calcined dolomite for the recarbonization significantly increased the $\mathrm{Ca}^{2+}$ and $\mathrm{Mg}^{2+}$ concentration in treated water. Maximum concentration of $\mathrm{Ca}^{2+}$ and $\mathrm{Mg}^{2+}$ ions in fluidised bed reactor was twofold higher than in a fixed bed reactor. Maximum recarbonization rate in the fluidised bed reactor was twice that in the fixed bed reactor. On the other hand, magnesium content was dominating (i.e. from 79.9 to $92.6 \%$ ) in treated water. A combination of half-calcined dolomite with a more abundant calcium content will be investigated in our further research.
Very good fit of experimental data for hydrodynamic characteristics of fluidised bed was obtained using a simple model based on the Richardson and Zaki expansion equation. The first order model describes a kinetic data from the recarbonization process with a good accuracy. Significant influence of carbon dioxide on the process performance resulted from the work. Higher rate of the recarbonization process was observed when using smaller particles fraction. On the other hand, higher calculated values of equilibrium concentration follow from the experiment carried out with the bigger particles fraction.

Based on the results presented, and taking into account the experience with the recarbonization fluidised bed reactor with two different fractions, we have decided to pursue further research using the larger particles fractions.

\section{Acknowledgements}

This work was supported by the Slovak Research and Development Agency under the contract No. APVV0656-12. The authors wish to thank also for the support of the VEGA Grant 1/0859/14. The study was also supported by The Programme Supporting Young Scientists STU.

\section{References}

1. J. Cotruvo, Water Conditioning \& Purification 2006, 48, 6-40.

2. L. F. Greenlee, D. F. Lawler, B. D Freeman., B. Marrot, P. Moulin, Water Research 2009, 43(9), 2317-2348.

http://dx.doi.org/10.1016/j.watres.2009.03.010

3. B. G. Ridoutt, S. Pfister, Global Environmental Change 2010, 20(1), 113-120. http://dx.doi.org/10.1016/j.gloenvcha.2009.08.003

4. M. A. Hanjra, M. E. Qureshi, Food Policy 2010, 35(5), 365377.

http://dx.doi.org/10.1016/j.foodpol.2010.05.006

5. M. Berger, M. Finkbeiner, Sustainability 2010, 2(4), 919944. http://dx.doi.org/10.3390/su2040919

6. C. Yang, X. Cui, Water 2014, 6(5), 1435-1452. http://dx.doi.org/10.3390/w6051435

7. Š. Olejko, Study of drinking water treatability and environmental aspects of water flows (Výskum upravite3/4nosti pitnej vody a environmentálne aspekty vodných tokov). Subtask 02: Treatment of drinking water mineralization. Final report of the task, VÚVH, Bratislava. In Slovak. 1999.

8. D. Hasson, O. Bendrihem, Desalination 2006, 190(1), 189200. http://dx.doi.org/10.1016/j.desal.2005.09.003

9. F. Elazhar, M. Tahaikat, M. El Azhar, Z. Jalili, A. Zouahri, M.Hafsi, A. El Midaoui, Int. J. Chem. Sci 2013, 11(4).

10. L. Birnhack, N. Voutchkov, O. Lahav, Desalination 2011, 273(1), 6-22.

http://dx.doi.org/10.1016/j.desal.2010.11.011 
11. L. Birnhack, N. Shlesinger, O. Lahav, Desalination 2010 , 262(1), 152-160 http://dx.doi.org/10.1016/j.desal.2010.05.061

12. J. Taylor, J. Dietz, A. Randall, S. Hong, Water Science \& Technology 2005, 51(6-7), 285-291.

13. D. P. Bang, Upflow limestone contactor for soft and desalinated water (Doctoral dissertation, MS Thesis, Delft University of Technology, Delft), 2012.

14. O. Lehmann, L. Birnhack, O. Lahav, Desalination 2013, 314, 1-9. http://dx.doi.org/10.1016/j.desal.2012.12.017

15. F. Kožíšek: Health and Regulatory Aspects of calcium and magnesium in drinking water. Calcium and Magnesium in Groundwater: Occurrence and Significance for Human Health, ISBN 978-1-138-00032-2, 2014, pp. 135-147.

16. I. Rosborg, F. Kozisek: Macrominerals at Optimum Concentrations-Protective Against Diseases. In Drinking Water Minerals and Mineral Balance, ISBN 978-3-319-09593-6, 2015. pp. 33-52. Springer International Publishing. http://dx.doi.org/10.1007/978-3-319-09593-6_3

17. M. Momeni, Z. Gharedaghi, M. M. Amin, P. Poursafa, M. Mansourian. International Journal of Preventive Medicine 2014, 5(2), 159-163.
18. S. Rapant, K. Fajčíková, V. Cvečková, A. Durža, B. Stehlíková, D. Sedláková, Z. Ženišová, Environmental geochemistry and health 2015, 1-12.

19. S. Dhodapkar, A. Zaltash, G. Klinzing, Chemical Engineering 2012, 119(8), 38-47.

20. J. F. Richardson, W. N. Zaki, Trans. Instn. Chem. Engineerings 1954, 32, 35-53.

21. G. R. Blake, K. H Hartge, in: Klute, A. (Ed.), Methods of Soil Analysis, Part I. Physical and Mineralogical Methods: Agronomy Monograph No. 9, second ed. 1986, pp. 363-375

22. STN EN 1017/AC, 2010

23. APHA, AWWA, WEF. In A. E. Greenberg, L. S. Clesceri, A. Eaton (Eds.), Standard methods for the examination of water and wastewater (22nd ed.). Washington, DC, USA: APHA, 2005.

24. J. Derco, M. Drtil, I. Bodík, M. Hutn̆an, in: Technológia a ochrana vodných zdrojov. Kurz dištančného vzdelávania-IDEP, STU Bratislava, Grantová podpora Nadácie otvorenej spoločnosti-Open Society Foundation. In Slovak. 2004.

25. M. Ye, M. A. van der Hoef, J. A. M. Kuipers, Chemical Engineering Science 2005, 60, 4657-4580.

http://dx.doi.org/10.1016/j.ces.2005.03.017

\section{Povzetek}

Razlog za nizko vsebnost mineralov v vodnih virih je v slabo topni mineralni geološki strukturi. Zato je pri pripravi pitne vode pomembna mineralizacija ki vključuje magnezij in kalcij predvsem tam, kjer jo pripravljajo z razsoljevanjem. Namen raziskav je bil proučevanje pospeševanja hitrosti karbonatizacije. Raziskave so potekale v reaktorju s fluidiziranim slojem polovično kalciniranega dolomita in prepihovanega $\mathrm{S}_{2}$-jem. $\mathrm{V}$ takšnem reaktorju se je hitrost karbonatizacije povečala za red velikosti v primerjavi z reaktorjem brez prepihovanja s $\mathrm{CO}_{2}$-jem. Doseženo je bilo zelo dobro ujemanje eksperimentalnih podatkov z izračunanimi po enostavnem modelu, ki upošteva hidrodinamske karakteristike reaktorja. Model prvega reda natančno opiše kinetične podatke karbonatizacije. Karbonatizacija poteka hitreje pri manjših delcih polovično kalciniranega dolomita. 